\title{
Morphological and Genetic Differences between Japanese and Chinese Red Ark Shell Scapharca broughtonii
}

\author{
Kōji Yokogawa \\ Kagawa Prefectural Fisheries Experimental Station, Yashimahigashimachi, Takamatsu, \\ Kagawa 761-01, Japan
}

(Received April 9, 1996)

\begin{abstract}
Morphological and genetic differences between Japanese and Chinese red ark shell Scapharca broughtonii were examined. Differences were recognized between the two forms in all of the morphological characters examined. In particular the number of radial costae and shell weight index differed sufficiently for unequivocal differentiation of the forms, when used in combination. Isozyme analyses of genetic characters indicated differences in allelic frequencies at the $M E P-I^{*}, P G M^{*}$ and $P R O T^{*}$ loci. The genetic distance (D value) between the Japanese and the Chinese forms, calculated from isozymic allele frequencies was 0.108 , suggesting significant genetic independency of the two forms. The considerable morphological and genetic differences suggested that the Chinese red ark shell is a distinct subspecies or species from Scapharca broughtonii.
\end{abstract}

Key words: ark shell, Scapharca broughtonii, morphology, genetics, isozyme, China

Red ark shell Scapharca broughtonii (Schrenck) is one of the most important shellfishes in fisheries in Japan and adjacent countries. In Japan, its artificial culture has been vigorously made. Since demand for aquacultural seeds increased in recent years, the supply of the seeds is not always sufficient. In Kagawa Prefecture, about 850 thousand of wild red ark shell (Fig. 1) were imported from China in 1993-1994 to supplement the shortage of the seeds. And the imported Chinese red ark shell were released into the natural sea area for farming.

Consequently, the effects of the existence of free-living Chinese red ark shell in Japanese waters is of concern, necessitating examination of their biological features. For this reason, the present study was carried out to clarify morphological and genetic differences between the Japanese and the Chinese red ark shells.

\section{Materials and Methods}

\section{Morphological Characters}

Data from specimens used for morphological analyses are shown in Table 1. The red ark shell from Japan (hereafter called Japanese form) were collected from off Kawarazu, Ehime Prefecture and from off Shido and off Takuma, Kagawa Prefecture, all the places being located in the Seto Inland Sea. Total number of the specimens was 87.

The red ark shell from China (hereafter called Chinese form) were sampled from aquacultural seeds, which were transported from Dalian, Liaoning Province, China to Kagawa Prefecture in February, 1994. They were originally caught in the Bohai Sea. Total number of the specimens was 82 .

As length-measured characters, shell length (SL), shell height (SH), shell depth (SD), hinge length (HL) and shell weight (SW) were measured. Meristically, number of radial costae (RC) and number of hinge teeth (HT) of the left valve were counted. To express the shell weight relatively, the shell weight index (SWI) was defined by a formula as follows:

$$
\mathrm{SWI}=\mathrm{SW} / \mathrm{SL}^{3} \cdot 10^{5}
$$

\section{Genetic Characters}

Data from specimens used for genetic analyses are shown in Table 1. Japanese forms were 24 of the 34 specimens collected from off Kawarazu, which were used for the morphological analyses. Chinese forms were 24 of the 82 specimens used for the morphological analyses. The specimens were preserved in a refrigerator at either $-80^{\circ} \mathrm{C}$ or $-30^{\circ} \mathrm{C}$.

Isozymes detected by horizontal starch-gel electrophoresis were used as genetic markers. Approximately $1 \mathrm{~g}$ of tissue was removed from the specimens in frozen condition, and it was put into a $1.5 \mathrm{~m} / \mathrm{micro}$ tube. In case of the diges-

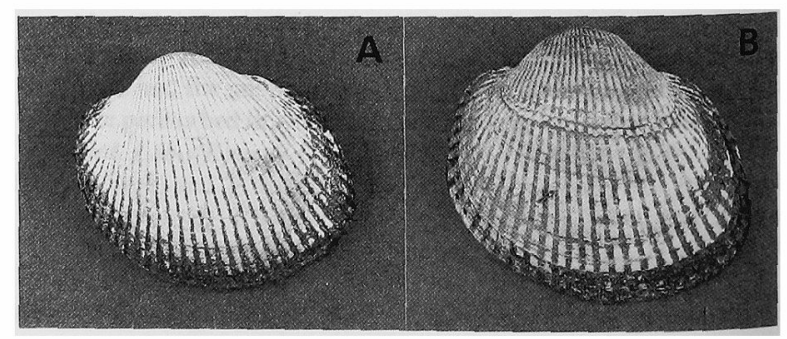

Fig. 1. General aspects of Chinese red ark shell with Japanese red ark shell.

A: Chinese form, SL $58.7 \mathrm{~mm}$, SH $48.6 \mathrm{~mm}$; B: Japanese form, SL $60.2 \mathrm{~mm}$, SH $49.2 \mathrm{~mm}$. 
Table 1. Collection and treatment data of specimens

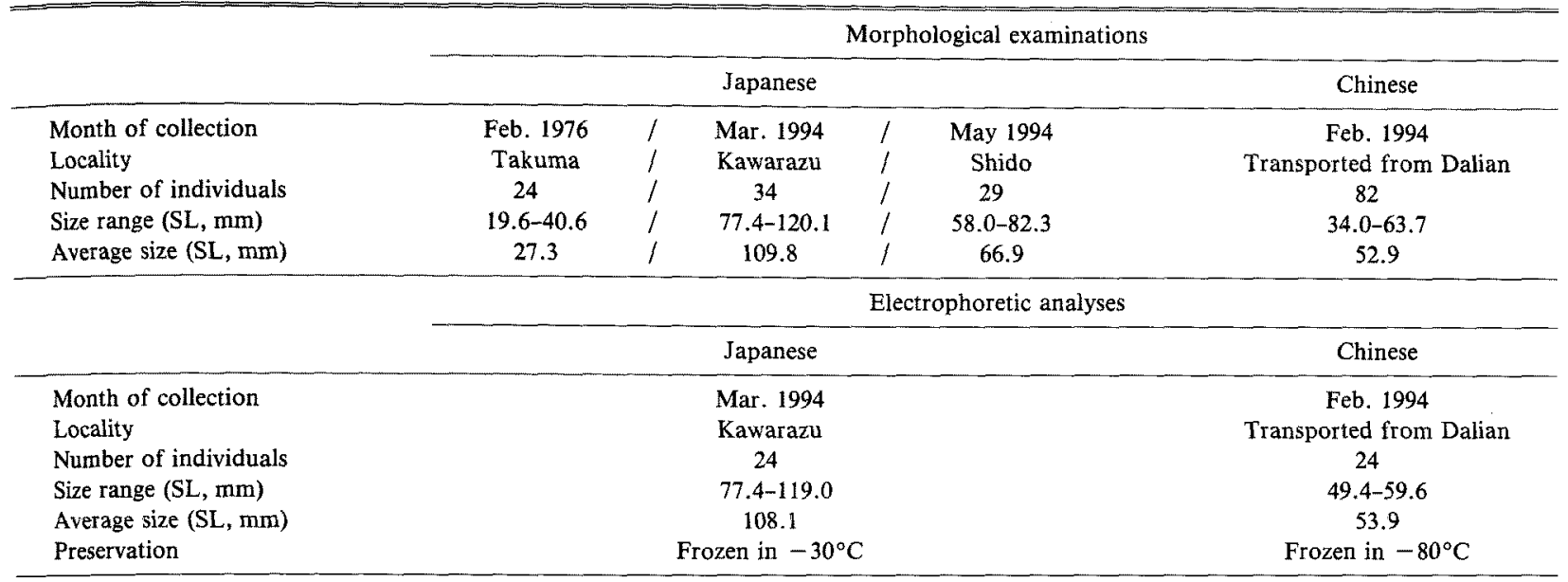

Table 2. Enzymes and protein examined, and tissues where they are detected

\begin{tabular}{|c|c|c|c|}
\hline Enzyme or protein name & Enzyme number & Locus & Tissue \\
\hline Aspartate aminotransferase & 2.6 .1 .1 & $A A T^{*}$ & Adductor Muscle \\
\hline Catarase & 1.11 .1 .6 & $C A T^{*}$ & Adductor Muscle \\
\hline \multicolumn{4}{|l|}{ Glyceraldehyde-3-phosphate de- } \\
\hline hydrogenase & 1.2 .1 .12 & $G A P D H^{*}$ & Adductor Muscle \\
\hline Glucose-6-phosphate isomerase & 5.3 .1 .9 & $G P I^{*}$ & Adductor Muscle \\
\hline Isocitrate dehydrogenase (NADP ${ }^{+}$) & 1.1 .1 .42 & $I D H P^{*}$ & Adductor Muscle \\
\hline \multirow[t]{2}{*}{ Leucine aminopeptidase } & 2.4 .11 & $L A P-L^{*}$ & Digestive Diverticulum \\
\hline & & $L A P-2^{*}$ & Adductor Muscle \\
\hline Malate dehydrogenase & 1.1 .1 .37 & $M D H^{*}$ & Adductor Muscle \\
\hline \multirow[t]{2}{*}{ Malic enzyme (NADP ${ }^{+}$) } & 1.1 .1 .40 & $M E P-I^{*}$ & Digestive Diverticulum \\
\hline & & $M E P-2^{*}$ & Digestive Diverticulum \\
\hline Mannose-6-phosphate isomerase & 5.3 .1 .8 & $M P I^{*}$ & Adductor Muscle \\
\hline Phosphogluconate dehydrogenase & 1.1 .1 .44 & $P G D H^{*}$ & Adductor Muscle \\
\hline Phosphoglucomutase & 5.4 .2 .2 & $P G M^{*}$ & Adductor Muscle \\
\hline General protein & & PROT* & Adductor Muscle \\
\hline
\end{tabular}

tive diverticulum tissue, the sample was directly homogenized, whereas for the adductor muscle tissue, the sample was homogenized with $100 \mu l$ of distilled water. Further, the samples were centrifuged by $15,000 \mathrm{rpm}$ for 10 minutes under $0^{\circ} \mathrm{C}$ condition, the supernatant fluid was used for the electrophoresis.

The electrophoretic experiment methods were based on Taniguchi and Okada, ${ }^{1)}$ using citric acid-aminopropylmorpholine buffer (pH 6.0) in each case. Enzymes and a protein detected by electrophoresis are shown in Table 2 . Gene nomenclature followed Shaklee et $a l .{ }^{2)}$ the alleles are symbolized as relative mobility percentages compared with the most dominant alleles identified. In addition, capital alphabet signs are also given to the alleles.

\section{Results}

\section{Morphological Characters}

Results of the morphological examinations are shown in Table 3. High level of significant differences in proportion between the two forms were recognized in all of the characters. SH, SD and SWI of the Chinese form were fairly larger than those of the Japanese form (Table 3). These matters indicate that the shell shape of the Chinese form is more global than the Japanese form, and the shell of the Chinese form is thicker than the Japanese form.

As for the meristic counts, the number of hinge teeth (HT) plainly increased associated with growth in the both forms (Fig. 2). Therefore, the average values and ranges of HT are not available to examine the difference between the two species (Table 3). Thus, regressions between SL and HT of the two forms were calculated. Powers regressions gave the highest correspondence to both the forms, being expressed by formulae as follows:

$$
\begin{array}{rr}
\text { Japanese form: } \mathrm{HT}=11.952 \cdot \mathrm{SL}^{0.410} & (r=0.942) \\
\text { Chinese form:HT }=15.702 \cdot \mathrm{SL}^{0.318} & (r=0.511)
\end{array}
$$

On the two formulae obtained, a covariance analysis was made. The $\mathrm{F}$ value resulted 2.080 , being significant at $1 \%$ level. That is, the regressions of the two forms are significantly different, according to the parameters of the formulae and the graph (Fig. 2), HT of the Chinese form are relatively less than that of the Japanese form.

Regarding the number of radial costae $(R C)$, since it did not vary with growth unlike $H T$, the average numbers and ranges were available to examine the differences between the two forms (Table 3). Histograms of RC frequencies in the two forms are shown in Fig. 3. Both resulted in plain 
Table 3. Proportional measurements and meristic counts of Japanese and Chinese forms with $t$ values between both average values

\begin{tabular}{|c|c|c|c|c|c|}
\hline & \multicolumn{2}{|c|}{ Japanese } & \multicolumn{2}{|l|}{ Chinese } & \multirow{2}{*}{$t$} \\
\hline & Average & Range & Average & Range & \\
\hline Shell height ${ }^{1}$ & 76.99 & $65.05-92.01$ & 84.21 & $75.59-92.22$ & $13.091^{* * *}$ \\
\hline Shell depth ${ }^{1}$ & 60.85 & $47.25-70.50$ & 67.60 & $55.88-85.14$ & $8.746^{* * *}$ \\
\hline Hinge length ${ }^{1}$ & 62.93 & $55.57-70.87$ & 60.21 & $53.25-69.41$ & $4.939^{* * *}$ \\
\hline Shell weight index & 7.78 & $5.40-10.70$ & 12.28 & $7.18-15.28$ & $18.958^{* * *}$ \\
\hline Hinge teeth & 67.58 & $38-94$ & 55.45 & $48-64$ & $6.856^{* * *}$ \\
\hline Radial costae & 41.25 & $39-44$ & 45.83 & $43-50$ & $21.614^{* * *}$ \\
\hline
\end{tabular}

1 Percentage of shell length.

*** Significant at $0.1 \%$ level.

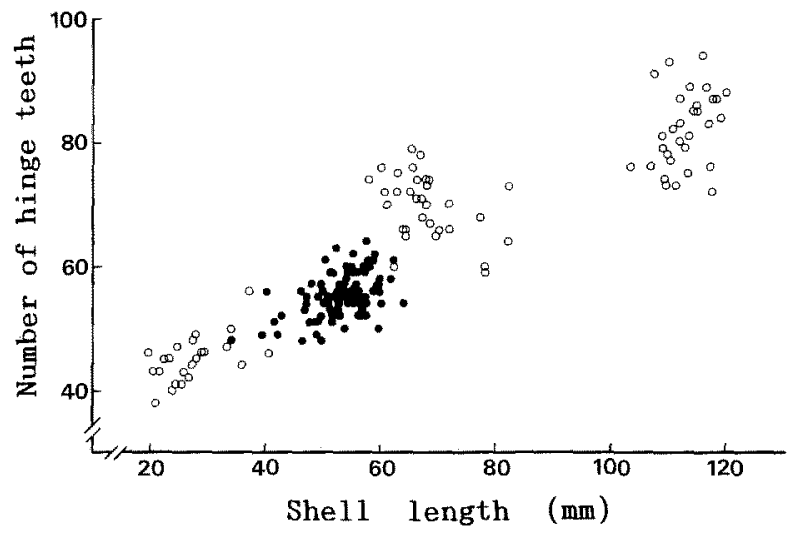

Fig. 2. Relationship between shell length and hinge teeth. Open circles-Japanese form, dark circles-Chinese form.

normal distributions and indicated clear differences in mode and range. The average values differing by nearly 5 between the two forms and slightly overlapping in the range of 43-44 (Fig. 3). Although the range of RC overlapped between the two forms, the combination with SWI separated the two forms completely (Fig. 4).

\section{Genetic Characters}

Allelic frequencies at 14 loci detected by electrophoresis with $\chi^{2}$ heterogeneities between the two forms are shown in Table 4, with some electrophoregrams of remarkable isozymes illustrated in Fig. 5. In addition to these loci, presence of 11 loci could be presumed in the other enzymes and protein such as acid phosphatase $\left(A C P-1^{*}, A C P-2^{*}\right.$, $\left.A C P-3^{*}\right)$, adenylate kinase $\left(A K^{*}\right)$, creatine kinase $\left(C K^{*}\right)$, esterase $\left(E S T-1^{*}, E S T-2^{*}\right)$, glycerol-3-phosphate dehydrogenase $\left(G 3 P D H^{*}\right)$, hemoglobin $\left(H B^{*}\right)$, octanol dehydrogenase $\left(O D H^{*}\right)$ and superoxide dismutase ( $\left.S O D^{*}\right)$. However, the enzymes and the protein were not available because they did not show enough activity or focusing of the zymograms was deficient.

The fitness of the allelic frequencies in polymorphic loci, according to Hardy-Weinberg equilibrium, was examined by chi-square test. Because no $\chi^{2}$ values were significant at the $5 \%$ level, the two forms were regarded as being originated from simple Mendelian populations respectively.

Regarding to heterogeneities between the groups, chisquare tests indicated significant differences in many of the

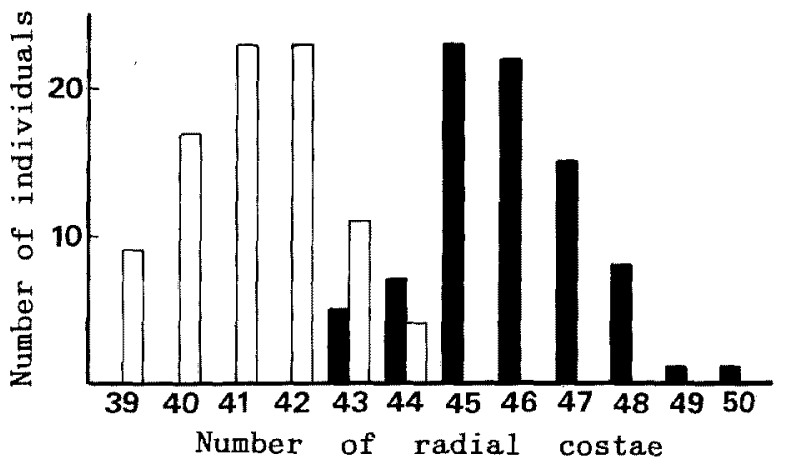

Fig. 3. Frequency distribution of radial costae. Open bars-Japanese form, dark bars-Chinese form.

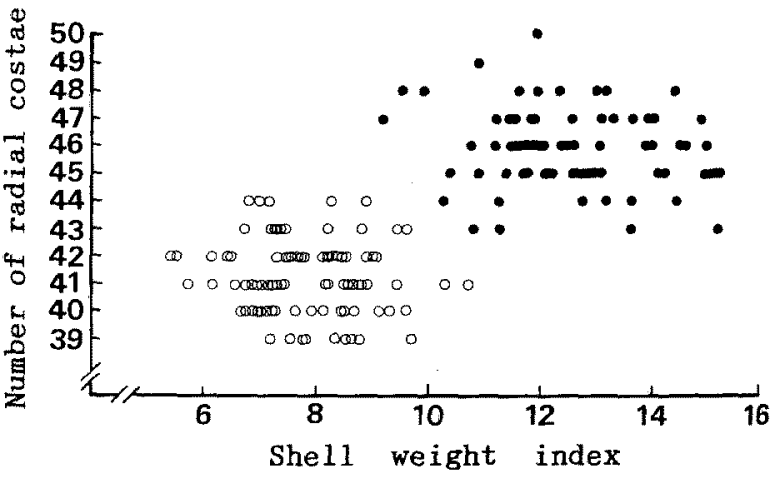

Fig. 4. Relationship between shell weight index and radial costae Open circles-Japanese form, dark circles-Chinese form.

loci examined (Table 4). Some of these loci and alleles are described as follows.

Malic enzyme (MEP): The $M E P-1^{*}$ locus of the Japanese form had a major allele of *100, and a minor one of ${ }^{*} 80$, whereas the locus in the Chinese form was monomorphic, being entirely occupied by the ${ }^{*} 100$ allele (Fig. 5 ; Table 4).

Phosphogluconate dehydrogenase (PGDH): The $P G D H^{*}$ locus of the Japanese form had a major allele of * 100 with a frequency of 0.917 , and a minor one $\left({ }^{*} 0\right)$, whereas in the Chinese form, the frequency of $* 100$ allele 0.844 , with minor allele of ${ }^{*} 0$ and ${ }^{*} 200$ (Fig. 5; Table 4).

Phosphoglucomutase (PGM): At the $P G M^{*}$ locus of the Japanese form, a major allele $\left({ }^{*} 100\right)$ with a frequency 
Table 4. Allelic frequencies of Japanese and Chinese forms with $\chi^{2}$ heterogeneities between both frequencies

\begin{tabular}{|c|c|c|c|c|c|c|c|c|c|}
\hline \multirow{2}{*}{ Locus } & \multirow{2}{*}{ Allele } & \multicolumn{2}{|c|}{ Frequency } & \multirow{2}{*}{$\chi^{2}$ hetero } & \multirow{2}{*}{ Locus } & \multirow{2}{*}{ Allele } & \multicolumn{2}{|c|}{ Frequency } & \multirow{2}{*}{$\chi^{2}$ hetero } \\
\hline & & Japanese & Chinese & & & & Japanese & Chinese & \\
\hline \multirow[t]{3}{*}{$A A T^{*}$} & ${ }^{*} 0 \mathrm{C}$ & 0.000 & 0.029 & 4.691 & $M D H^{*}$ & $* 170 \mathrm{~B}$ & 0.083 & 0.000 & $4.364^{*}$ \\
\hline & ${ }^{*}-100 \mathrm{~A}$ & 0.977 & 0.853 & & & $* 100 \mathrm{~A}$ & 0.917 & 1.000 & \\
\hline & ${ }^{*}-200 \mathrm{~B}$ & 0.023 & 0.118 & & $M E P-1^{*}$ & $* 100 \mathrm{~A}$ & 0.682 & 1.000 & $15.771^{* * *}$ \\
\hline \multirow[t]{3}{*}{$C A T^{*}$} & ${ }^{*} 100 \mathrm{~A}$ & 0.875 & 0.979 & 4.276 & & $* 80 \mathrm{~B}$ & 0.318 & 0.000 & \\
\hline & ${ }^{*} 75 \mathrm{~B}$ & 0.104 & 0.021 & & $M E P-2^{*}$ & ${ }^{*}-40 \mathrm{~B}$ & 0.405 & 0.214 & 5.235 \\
\hline & ${ }^{*} 65 \mathrm{C}$ & 0.021 & 0.000 & & & $*-100 \mathrm{~A}$ & 0.452 & 0.548 & \\
\hline \multirow[t]{2}{*}{$G A P D H^{*}$} & $* 120 \mathrm{~B}$ & 0.021 & 0.021 & 0.000 & & $*-180 \mathrm{C}$ & 0.143 & 0.238 & \\
\hline & ${ }^{*} 100 \mathrm{~A}$ & 0.979 & 0.979 & & $M P I^{*}$ & ${ }^{*} 100 \mathrm{~A}$ & 0.438 & 0.167 & $11.089^{*}$ \\
\hline \multirow[t]{2}{*}{$G P I^{*}$} & $* 100 \mathrm{~A}$ & 0.750 & 0.771 & 1.048 & & ${ }^{*} 95 \mathrm{~B}$ & 0.479 & 0.667 & \\
\hline & *80 B & 0.250 & 0.229 & & & ${ }^{*} 50 \mathrm{C}$ & 0.083 & 0.167 & \\
\hline \multirow[t]{2}{*}{$I D H P^{*}$} & ${ }^{*} 100 \mathrm{~A}$ & 0.771 & 0.813 & 2.199 & $P G D H^{*}$ & ${ }^{*} 200 \mathrm{C}$ & 0.000 & 0.094 & 5.755 \\
\hline & $* 75 \mathrm{~B}$ & 0.229 & 0.188 & & & $* 100 \mathrm{~A}$ & 0.917 & 0.844 & \\
\hline \multirow[t]{2}{*}{$L A P-I^{*}$} & ${ }^{*}-100 \mathrm{~A}$ & 0.964 & 0.864 & 1.387 & & ${ }^{*} 0 \mathrm{~B}$ & 0.083 & 0.063 & \\
\hline & $*-160 \mathrm{~B}$ & 0.036 & 0.136 & & $P G M^{*}$ & ${ }^{*} 125 \mathrm{D}$ & 0.000 & 0.042 & $25.329^{* * *}$ \\
\hline \multirow[t]{4}{*}{$L A P-2^{*}$} & ${ }^{*} 115 \mathrm{C}$ & 0.021 & 0.022 & 3.123 & & ${ }^{*} 120 \mathrm{~B}$ & 0.021 & 0.375 & \\
\hline & ${ }^{*} 100 \mathrm{~A}$ & 0.771 & 0.761 & & & $* 100 \mathrm{~A}$ & 0.979 & 0.521 & \\
\hline & *90 B & 0.208 & 0.196 & & & ${ }^{*} 85 \mathrm{C}$ & 0.000 & 0.063 & \\
\hline & ${ }^{*} 70 \mathrm{D}$ & 0.000 & 0.022 & & $P R O T^{*}$ & *175 B & 0.130 & 0.938 & $38.996^{* * *}$ \\
\hline
\end{tabular}

* Significant at $5 \%$ level.

** Significant at $1 \%$ level.

*** Significant at $0.1 \%$ level.

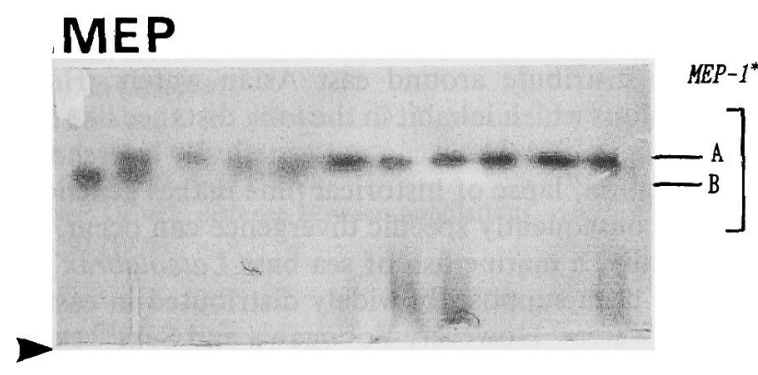

$B B \quad A B$ AA $A A \quad A A$ AA $A A$ AA AA AA $A A$

Japanese form $\quad$ Chinese form

\section{PGDH}

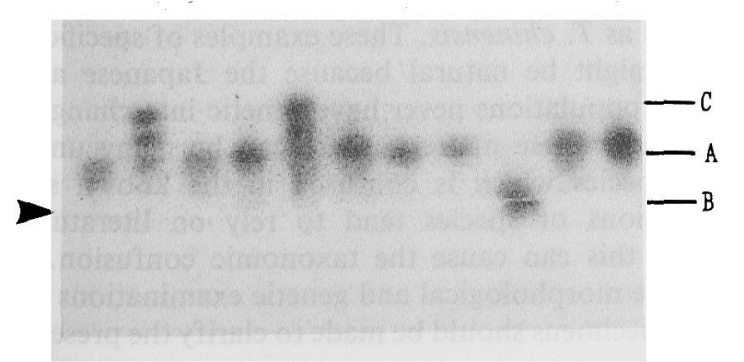

AA AC AA AA AC AA AA AA BB AA AA

Chinese form Japanese form

\section{PGM}

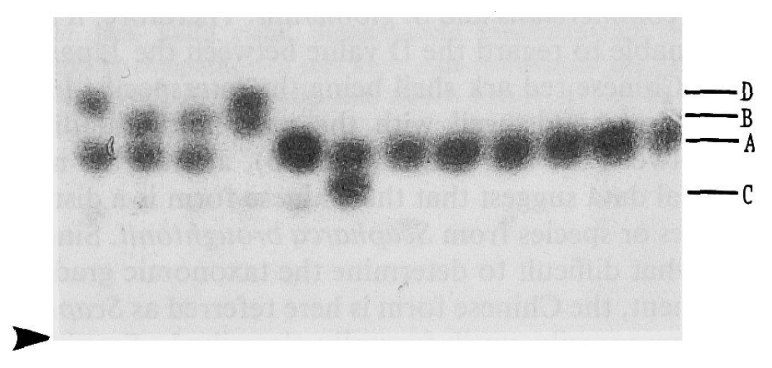

$A D \quad A B \quad A B \quad B D \quad A A \quad A C \quad A A \quad A A \quad A A \quad A A \quad A A \quad A A$

Chinese form Japanese form

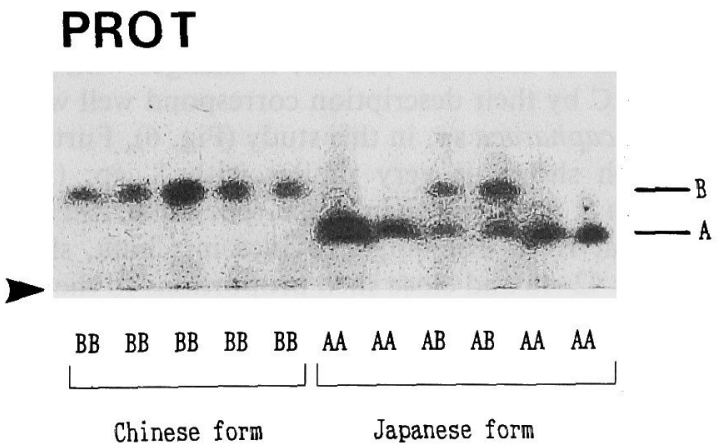

Fig. 5. Selected electrophoretograms of some loci in Japanese and Chinese forms. 
of 0.979 , and a minor one $\left({ }^{*} 120\right)$ were found, whereas the Chinese form had the ${ }^{*} 100$ allele as the major allele, with a frequency of 0.521 , and minor ones of ${ }^{*} 120,{ }^{*} 85$ and ${ }^{*} 125$ (Fig. 5; Table 4).

General protein (PROT): At the PROT ${ }^{*}$ locus of the Japanese form, the major allele of $* 100$ had a frequency of 0.870 , with a minor allele of ${ }^{*} 175$. In contrast, in the Chinese form, the major and minor alleles were essentially reversed, with the major allele being ${ }^{*} 175$, with a frequency of 0.938 , and the minor one $\left({ }^{*} 100\right)$ (Fig. 5; Table 4).

Of the other isozymes, significant differences in allelic frequencies between the two forms were found in the $M D H^{*}$ and $M P I^{*}$ loci (Table 4).

The genetic distance (D value) ${ }^{3)}$ between the two forms, calculated from isozymic allele frequencies was 0.108 , at least significant at the intersubspecific level of general livings. ${ }^{4}$

\section{Discussion}

According to the genetic analysis, the $D$ value between the two forms was 0.108 . Although the value was significant at the interspecific level of general livings, ${ }^{4)}$ it was somewhat lower than the general interspecific level of marine bivalves (intrageneric average 0.248-0.974) summarized by Oniwa and Kijima. ${ }^{5}$ However, some of the D values shown by them are smaller than the value obtained in this study, such as 0.098 which is between Crassostorea gigas and $C$. angulata, and 0.079 which is between $S a c$ costorea commercialis and $S$. glomerata. Therefore, it may be reasonable to regard the $\mathrm{D}$ value between the Japanese and the Chinese red ark shell being the interspecific level.

This corresponds well with the morphological divergence between the two forms (Table 3), at least the morphological data suggest that the Chinese form is a distinct subspecies or species from Scapharca broughtonii. Since it is somewhat difficult to determine the taxonomic grade in this moment, the Chinese form is here referred as Scapharca sp. temporarily until formally described. Scapharca broughtonii is supposedly widely distributed in coastal waters of the Japanese Archipelago, Korea, northern China and Taiwan. ${ }^{6-8)}$ This study showed that a distinct subspecies or species, formerly confused with Scapharca broughtonii, inhabits the Chinese coast.

Wang et al. ${ }^{7}$ described so-called $S$. broughtonii in China, indicating $\mathrm{HT}$ as about 70 and $\mathrm{RC}$ as $42-48$. Although HT can not be discussed because it changes with growth (Fig. 5), RC by their description correspond well with the result of Scapharaca sp. in this study (Fig. 6). Further, its photograph shown is very similar with $S$. sp. (Fig. 1) rather than $S$. broughtonii in shape. The same, Zheng ${ }^{9}$ described that from Zhejiang Province in China, showing $\mathrm{RC}$ also as $42-48$ and close shell proportions to the results in this study.

While Qi et al. ${ }^{10)}$ also described the same species and indicated RC as 42 . However, their description is doubtful because RC can be counted at least 44 from the plate they showed. Further, its photograph shown is similar with $S$. sp., and the calculated proportion from their data shown also correspond well with $S$. sp. Therefore, their description might be based on Japanese descriptions on $S$, broughtonit.

Lee et al. ${ }^{* 1}$ examined characteristics of Korean red ark shell from Chinhae Bay and Chinese one from Shandong Province with morphometrics and nuclear DNA analyses. They detected considerable morphological and genetic differences between the Korean and the Chinese forms as same as this study.

Since differences between the Japanese and the Korean forms have not been examined yet, it is uncertain whether these two forms are the same species or not. However, the capture locality of the Korean form examined in their study is faced Tsushima Channel that is close to Japanese Archipelago. According to a description of $S$. broughtonii in Korea, the Korean form is very similar with the Japanese form. ${ }^{11)}$ Jo et al. ${ }^{12)}$ examined regression between SL and SH and that between SL and SD of the Korean ark shell from east coast of the Korean Peninsula, and showed close allometric values to the Japanese form examined in this study.

Although the information does not always mean that an uniform species distributes around Korean Peninsula, at least some Korean populations like that examined by Lee et $a l{ }^{* 1}$ and Jo et $a l{ }^{12)}$ may be the same species as the Japanese form. Suppose this was true, the fact that there were pronounced differences between the Korean and the Chinese forms was reasonable.

There are many living species which is supposed to broadly distribute around east Asian waters. However, populations which inhabit in the long distance like that between Japan and China can not genetically interchange. In the situation, lapse of historical time makes genetic divergence, consequently specific divergence can occur.

Actually, a marine fish of sea bass Lateolabrax japonicus has been supposedly widely distributed in east Asian coastal waters. However, Yokogawa and Seki ${ }^{13)}$ examined morphological and genetic differences between the Japanese and the Chinese sea bass, and concluded that the Chinese one is a different species from $L$. japonicus as same as the Chinese red ark shell in this study. The same, Ozawa and Tomida ${ }^{14)}$ made morphological comparison between Japanese and Chinese top shell Turbo (Batillus) cornutus, they recognized the Chinese top shell as a distinct species from the Japanese one, and described the Chinese top shell as $T$. chinensis. These examples of specific divergences might be natural because the Japanese and the Chinese populations never have genetic interchange.

Not only these matters, there can be many unknown living species which is confused in the known species. Descriptions of species tend to rely on literature and reports, this can cause the taxonomic confusion. Hereafter, the morphological and genetic examinations for the actual specimens should be made to clarify the present classifications.

Actually, not only the red ark shell but also many kinds of foreign fishes and shellfishes have been vigorously introduced into Japan as aquacultural seeds. ${ }^{* 2}$ And some

\footnotetext{
*1 Lee et al.: Abst. 1st Metg. Korea-Japan Aaquacult. Sci. Sympo. May, 1994, p. 154-156 (in Korean).
}

*2 Yokogawa: Abst. 1st Metg. Korea-Japan Aaquacult. Sci. Sympo. May, 1994, p. 36-37 (in Japanese). 
species of the foreign seeds genetically differed from Japanese native species. ${ }^{13,15,16) * 3, * 4}$ In case of the Chinese red ark shell, it must be a great problem that the seeds were released into the open sea. The free-living individuals will grow up and mature, they may participate the propagation with the Japanese ones. It can cause hybridization between the two forms. If the $F_{1}$ hybrids can propagate, the exotic gene will flow into the Japanese native gene resources, and that status can not return to the original condition by any means.

Therefore, in order to conserve the Japanese native genetic resources, it would be recommended that new introductions of the foreign seeds should be made with enough caution from now on.

Acknowledgments The author is very grateful to Mr. Ken-ichi Yamaga, Kagawa Prefectural Fisheries Experimental Station, who motivated to make this study and willingly offered the Chinese red ark shell specimens. Mr. Shinji Hirata, Ehime Prefectural Chūyo Fisheries Experimental Station, Mr. Fusanori Yakushiji, Töyo branch of Ehime Prefectural Chūyo Fisheries Experimental Station, Mr. Chiyoteru Shimokawa, Fisheries Division of Kagawa Prefectural Government and Dr. Sadaaki Yoshimatsu, Kagawa Prefectural Red Tide Institute, assisted in collecting samples of the Japanese red ark shell specimens. Dr. Yasuo Kondo, Faculty of Science, Köchi University and Mr. Ken-ichi Nakao, Tokushima Prefectural Museum, provided some literature. Dr. Shi Dong, Faculty of Agriculture, Köchi University, assisted in translating Chinese literature.

\section{References}

1) N. Taniguchi and Y. Okada: Genetic study on the biochemical polymorphism in red sea bream. Nippon Suisan Gakkaishi, 46, 437-443 (1980) (in Japanese).

2) J. B. Shaklee, F. W. Allendorf, D. C. Morizot, and G. S. Whitt: Gene nomenclature for protein-coding loci in fish. Trans. Amer. Fish. Soc., 119, 2-15 (1990).

3) M. Nei: Genetic distance between populations. Amer. Nat., 106, 283-292 (1972).
4) M. Nei: Molecular evolutionary genetics (Translated from English by T. Gojobori and N. Saito), Baifukan, Tokyo, 1990, p. 433 (in Japanese).

5) K. Oniwa and A. Kijima: Genetic distance between species in marine bivalves. Fish Genet. Breed. Sci., 14, 27-32 (1989) (in Japanese).

6) T. Okutani: 50 species of marine shells. Green Books 6, New Science Co., Tokyo, 1980, p. 103 (in Japanese).

7) R. Wang, Q. Zhang, X. Qu, Y. Cai, and Y. Zhang: Coloured illustrations of aquatic mollusks in China, Zhejiang Publ. House Sci. Tech., Hangzhou, 1988, p. 255 (in Chinese).

8) F. R. Bernard, Y. Cai, and B. Morton: Catalogue of the living marine bivalve molluscs of China, Hong Kong Univ. Press, Hong Kong, 1993, p. 146.

9) F. Zheng: Order Taxodonta, in "Fauna of Zhejiang, mollusks" (ed. by R. Cai and W. Huang), Zhejiang Sci. Tech. Publ. House, Hangzhou, 1989, pp. 152-161 (in Chinese).

10) Z. Qi, X. Ma, Z. Wang, G. Lin, F. Xu, Z. Dong, F. Li, and R. Lü: Mollusca of Huanghai and Bohai, Agri. Publ. House, Beijing, 1989 , p. 309, 13pls. (in Chinese).

11) J. Yoo, 1976. Korean shells in colour. Iljisa Publ., Seoul, 1976, p. 196 (in Korean).

12) M. Jo, K. Byun, K. Lim, S. Son, S. Lee, C. Baik, Y. Park, S. Choi, J. Hong, G. Kim, K. Sung, S. Lee, and K. Kwun: Distribution and ecology of major shellfishes in the coastal area of Kyongsangbukdo. Bull. Nat. Fish. Res. Dev. Agency, 51, 23-66 (1995) (in Korean).

13) K. Yokogawa and S. Seki: Morphological and genetic differences between Japanese and Chinese sea bass of the genus Lateolabrax. Japan. J. Ichthyol., 41, 437-445 (1995).

14) T. Ozawa and S. Tomida: A new Turbo (Batillus) species from Chinese coasts. Venus, 54, 269-277 (1995).

15) K. Yokogawa, N. Taniguchi, and T. Mukai: Morphological and genetic differences between Japanese and Korean black rockfish Sebastes inermis. Bull. Mar, Sci. Fish. Kochi Univ., 11, 89-94 (1989).

16) Y. Furukawa, Y. Natsukari, and M. Yoshimoto: Ecological study of jack knife clam, Sinonovacula constricta-XI, population genetic comparison of jack knife clam from Japan and Korea. Bull. Saga Pref. Ariake Fish. Res. Devel. Center, 17, 15-18 (1996) (in Japanese).

${ }^{*}$ Furukawa et al.: Abst. Metg. Japan. Soc. Fisheries Sci., October, 1993, p. 91.

*4 Yokogawa: Abst. 2nd Japan-Korea Joint Metg. Sympo. Aaquacult. July, 1996, pp. 33-34 (in Japanese). 